\title{
An overview of quality and safety in health care
}

\author{
Alan F. Merry, MBChB
}

Received: 5 August 2012/ Accepted: 27 November 2012/Published online: 12 December 2012

(c) Canadian Anesthesiologists' Society 2012

Patient safety is of prime importance to anesthesiologists; there are, however, other dimensions to quality in health care that also merit our attention. Anesthesia is not a treatment in itself but is integral to achieving successful outcomes for surgical patients; therefore, it is equally as important as any other aspect of patient care. Furthermore, anesthesia often equals or exceeds surgery with respect to the challenges involved, the resources required, and the risk to patients. These factors are reflected in the high standards of training, practice, and research that are characteristic of modern anesthesia in many (but not all) parts of the world. These standards are hard won, and maintaining and advancing them will continue to require considerable effort and investment in the face of increasing international financial restraint. It therefore behooves anesthesiologists to understand how the services they provide contribute to the overall quality of health care.

\section{The central importance of safety in anesthesia}

Many patients suffer avoidable harm from the health care intended to help them. ${ }^{1}$ More than a decade ago, the

A. F. Merry is Chair of the Health Quality and Safety Commission, New Zealand.

A. F. Merry, MBChB ( $₫)$

Department of Anaesthesiology, University of Auckland, Private Bag 92019, Auckland 1142, New Zealand

e-mail: a.merry@auckland.ac.nz

A. F. Merry, MBChB

Department of Anaesthesia, Auckland City Hospital, Auckland, New Zealand
Institute of Medicine called for initiatives to reduce this harm. $^{2}$ It is therefore gratifying that anesthesiologists have a long-standing reputation for advancing patient safety $^{3}$ which is supported by numerous examples, including (amongst others) the establishment of the Anesthesia Patient Safety Foundation (APSF) in 1985 under the leadership of Jeep Pierce ${ }^{4}$ with the mission to "ensure that no patient is harmed by anesthesia"; the establishment of the Australian Patient Safety Foundation in 1988 by Bill Runciman, ${ }^{5}$ also with the aim of reducing harm to patients; at about the same time, David Gaba's introduction to anesthesiology of the concepts of "Normal Accident Theory"; 6 the early adoption of reporting and learning from incidents, including near misses, by Jeff Cooper $^{7}$ and Bill Runciman; ${ }^{8}$ and the uptake of simulation as a tool for teaching and research in anesthesia. ${ }^{9-12}$

This intense focus on patient safety is appropriate as anesthesia is intrinsically dangerous. Even in wellresourced parts of the world, substantial reductions in mortality from anesthesia have occurred only relatively recently. ${ }^{13}$ In some low-income regions, resources for anesthesia are completely inadequate and perioperative mortality is unacceptably high. ${ }^{14}$ Even in high-income regions, there is debate over the extent of improvement achieved and over the precise present-day anesthesia mortality. ${ }^{3,15}$ This debate is due in part to the lack of an international consensus on the relevant definitions. Tragically, preventable deaths still occur, with causes ranging from medication errors ${ }^{16}$ to failures in managing difficult airways. ${ }^{17}$ In older patients with comorbidities, mortality may well be higher than has sometimes been appreciated, ${ }^{18,19}$ and it may be influenced not only by the conduct of anesthesia but also by the management of the entire perioperative period. ${ }^{19,20}$ 


\section{Mortality and morbidity attributable to anesthesia}

Given the central importance of safety in anesthesia, it is disappointing that, with the arguable exception of Australia and (recently) New Zealand, ${ }^{13,21}$ we lack data to define unequivocally the mortality associated with anesthesia today and its progress over time. The available data typically relate to only the first 24 or $48 \mathrm{hr}$ after surgery. Many relevant deaths are missed with periods of this length, ${ }^{18,19}$ although these measurements may still function as a useful indicator of standard of anesthesia care and a means of monitoring change over time. The importance of indicators to define the state of surgical services (including anesthesia) at a national level is reflected by the fact that the World Health Organization's Safe Surgery Saves Lives initiative included the development of several simple and widely applicable measures for this purpose, including two practical definitions of perioperative mortality: a) dayof-surgery death ratio, and b) postoperative in-hospital death ratio. ${ }^{22}$ Monitoring the former ought to be within the capability of any hospital carrying out surgery under anesthesia, and the latter within the capability of most. Where resources are more plentiful, a longer period (e.g., 30 days) will give a more accurate picture of anesthesia mortality. It is also worth including patients who did not receive surgery when it might have been lifesaving as well as patients who underwent procedures under anesthesia that traditionally have not been regarded as surgical (e.g., angioplasty and endoscopy). ${ }^{21}$ Reviewing cases to determine the cause of death is time-consuming but can contribute valuable information for improving the care of future patients. There is increasing evidence that teamwork and communication are key determinants of outcome, ${ }^{23-27}$ so it is important to understand not only the contribution of factors related to surgery, anesthesia, and the patient but also the interaction of these factors. Thus, analysis is more likely to be productive if carried out by members of the entire perioperative team rather than by a single craft group.

Anesthesia results in morbidity more often than mortality; therefore, morbidity should also be reviewed and reported. There are valuable lessons to learn from analysis of any cases in which harm has occurred or might have occurred. ${ }^{13}$

\section{The escalating costs of health care and the Triple Aim}

Over recent decades, the costs of health care in many countries have increased more rapidly than the gross domestic product (GDP). ${ }^{28}$ For example, health care expenditure in the USA in 2001 was $13.5 \%$ of the GDP. This increased to $16 \%$ by 2007 , and it is projected to reach nearly $20 \%$ by 2020 . This trend has occurred against a backdrop of international financial challenges not seen since the great depression of the 1930 s. In its "Triple Aim", the Institute for Healthcare Improvement encapsulates the need to contain this increase in expenditure by optimizing the performance of health care. ${ }^{29,30}$

This involves the simultaneous pursuit of three dimensions:

- Improving the patient experience of care (including quality and satisfaction);

- Improving the health of the population; and

- Reducing the per capita cost of health care.

A refinement adopted nationally in New Zealand ${ }^{31}$ reframed the third aim as "obtaining the best value from public health system resources". This reflects a view that health care expenditure might not need to be reduced (at least in countries where it is still considerably lower than in the USA), but waste is certainly unaffordable.

It seems intuitive that achieving these three aims will be facilitated considerably by two primary objectives: a) doing the right things and b) doing them right the first time. Safety is key, but the other elements of quality also matter. In addition to safety, these elements include timeliness, efficiency, efficacy, equitability, and patient-centredness (captured by the acronym STEEEP). ${ }^{32}$

\section{Improving quality in health care}

Facilitating the timely provision of critical procedures is central to the role of anesthesiologists. Nevertheless, there is still a need to address ongoing failures in timeliness of certain important aspects of anesthesia practice. A key element of the World Health Organization's (WHO) Surgical Safety Checklist ${ }^{23}$ relates to the need to ensure the timely administration of prophylactic antibiotics, when indicated. Timely progression through the steps of an appropriate algorithm is critical to managing unexpected difficulties with patients' airways, but failures to do this still occur regularly. ${ }^{17}$

The drivers for efficiency are strong in anesthesia. Inefficiency creates opportunity costs that may impact negatively on outcomes, particularly at a population level. Money spent on one thing cannot be spent on another; resources are limited, and inadequate access to effective treatment is a major source of harm in health care. Nevertheless, efficiency should be judged on the outcomes achieved with the resources available. It is not necessarily true that faster and cheaper anesthesia services will save money overall, it takes little harm to offset any savings made by cutting corners. The Triple $\mathrm{Aim}^{30}$ is helpful to articulate the requirement for balance between efficiency 
and the other elements of quality in health care, particularly the New Zealand version ${ }^{31}$ with its emphasis on obtaining the best value from the available resources rather than necessarily reducing cost.

A timely and efficient service is of little value if the treatments provided are not efficacious. There is a distinction between efficacy and effectiveness, and both are important. Effectiveness relates to the impact on outcomes of a particular treatment, medication, or intervention (e.g., to improve safety) in actual practice. Anesthesiologists are accustomed to using highly efficacious medications effectively-many of our agents work every time (with the number needed to treat being one!), but much care and attention to detail is needed to use them effectively without killing our patients. The antibiotic element of the WHO Surgical Safety Checklist is intended to improve the effectiveness of antibiotics with proven efficacy. ${ }^{23}$ Large randomized controlled trials (RCTs) that address simple but important questions in clinical practice, with substantive patient outcomes as endpoints, are the cornerstone of advancing effectiveness in anesthesia; a number of excellent examples have been published in recent years. ${ }^{33-36}$ The establishment of formal networks, such as the Outcomes Research Consortium, ${ }^{37}$ the Australian and New Zealand College of Anaesthetists (ANZCA) Trials Group, ${ }^{38}$ and the Australian and New Zealand Intensive Care Society (ANZICS) Clinical Trials Group ${ }^{39}$ has substantially facilitated the conduct of large high-quality RCTs to provide reliable and clinically relevant evidence to guide the management of patients undergoing surgery or requiring critical care.

As an anesthesiologist, it could be tempting to forget about equitability and to take the view that one's only responsibility at any point in time is the wellbeing of the patient immediately at hand. Given the constraints on resources discussed above, this position is simply not sustainable. $^{28}$ There is a good basis for believing that improving the equitability of health care improves outcomes across the board, not just for previously disadvantaged segments of the population. ${ }^{40}$ One reason for this belief lies in the phenomenon of unwarranted variation in health care. We are overtreating some patients while undertreating others; a more equitable redistribution of health care would address both of these problems without needing any increase in resources. The idea that more is better in health care is embedded in the culture of many modern societies, and the incentive for health care professionals to promulgate this view is considerable. It is interesting, therefore, that mortality rates tend to stay level or decrease when doctors go on strike. ${ }^{41}$ There are several possible explanations for these counterintuitive findings, but they are consistent with other evidence ${ }^{1,2}$ that (to quote the authors) highlights "the risks of elective surgeries, which may actually increase mortality. They also highlight the possibility that an oversupply of doctors may not increase patient survival and may introduce inefficiencies into health care". 41

Before discussing variation in health care in more detail, it is worth reflecting on the importance of patient-centred care. ${ }^{42}$ It is increasingly clear that well-informed patients do not necessarily demand every available treatment., ${ }^{1,43}$ Patients who are engaged in their own care and have a reasonable understanding of their options (including the option of doing nothing) are likely to make better choices and contribute more constructively to their own safety than those who are not. ${ }^{44}$ It is also important for all those involved with caring for patients within the complex system of modern health care to communicate constructively with each other and to be united both in their messages to patients and in their efforts to treat them. ${ }^{45}$ The influence of improved teamwork and communication on the outcomes of surgery has been mentioned above. ${ }^{23-27}$ A collaborative approach that is both interprofessional and patient-centred offers the best chance of success in providing patients with outcomes that are aligned with their own values rather than in those values that health professionals perceive to be important.

\section{Variation in health care}

Even in wealthy countries, there is often substantial variation in the care patients receive and in the outcomes of that care. ${ }^{46,47}$ For example, Birkmeyer et al. showed the ratio of the highest to the lowest hospital referral regions for carotid endarterectomy for Medicare enrollees in the USA to be approximately 10 to $1 .^{46}$ Variation based on differences between patients is appropriate, but this variation was not explained by case mix or even by differences in resource. Instead, variation of this type seems typically to reflect regional differences in the approach of providers, ${ }^{46,48}$ although prejudice on one hand and patient preferences on the other may also be factors. ${ }^{4-51}$ Areas receiving the greatest investment in health care or the most interventions do not necessarily have the best outcomes. ${ }^{51}$

Showing variation on its own does not allow us to determine which rate is correct, but given similar patients, the highest and the lowest rates cannot both be accurate. Variation in health care usually includes undertreatment and overtreatment, both of which carry risk for patients. Appropriate treatment also carries risk, but in this case, the risk is justified by a reasonable expectation of benefit. By contrast, if a harmful error is made during a procedure that was not truly justified by evidence of efficacy or during one that would not have been truly desired by the patient if fully informed, then the root cause of such harm is not the 
error (which is a more proximal cause) but rather the decision to undertake the procedure in the first place. Even if carried out perfectly, such procedures carry an opportunity cost.

Variation in the provision of health care is particularly obvious from an international perspective. Some 35\% of the world's population accesses only $3.5 \%$ of the 230 million surgical procedures undertaken around the world annually, ${ }^{52}$ and the quality of anesthesia care this group of people receives is typically inadequate. ${ }^{14}$ The greatest potential for improvement in the global outcomes of health care (including anesthesia) lies in low-income regions of the world (some of which are located in countries with high or middle incomes overall). This potential does not lie in continuing to accept inadequate care as inevitable; instead, it lies in initiatives to raise standards to an acceptable level as inexpensively as possible..$^{53,54}$

\section{Measurement and evaluation}

Although some initiatives should be undertaken simply because they make sense, ${ }^{55}$ measurement is fundamental to quality improvement, and the possibility of unanticipated "revenge" effects from well-intended initiatives must not be forgotten. ${ }^{56}$ Donabedian's framework of structure, process, and outcome is widely used. ${ }^{57}$ Outcome measures are the most important, but they are also the most difficult to measure. Measuring process may be particularly effective in promoting improvements in quality because process measures (e.g., the rate of hand washing) are not typically influenced by case mix, so comparisons between institutions or over time are often more robust than comparisons in outcomes (e.g., the incidence of health care-associated infections).

Survival is an important outcome that captures the public imagination, so it is not surprising that iatrogenic harm is sometimes quantified in terms of lives $\operatorname{lost}^{2}$ or that some safety initiatives have promoted the explicit aim of saving lives. ${ }^{58}$ It turns out that lives lost or saved are difficult to measure. ${ }^{59,60}$ Attribution of the cause of death is often difficult in the context of high-level interventions to improve the overall function of a complex health care system. Furthermore, lives saved do not always seem equal-how does one compare the last three months of an elderly patient's life in poor health with the entire future life of a healthy child? Quality adjusted life years (QALYS) seem more meaningful, albeit with less mass appeal, but making judgements on the quality of other people's lives does not align well with the concept of patientcentred care. Mortality, discussed above, is a different matter. At national and institutional levels, with appropriate correction for case mix and risk factors (American Society of
Anesthesiologists [ASA] categories and age go a long way in the context of anesthesia), it has the potential to provide objective data of great value, and a more widespread commitment to measuring anesthesia mortality is overdue.

Pronovost $e t$ al. have provided a very thoughtful outline of the issues to consider in research evaluating quality and safety initiatives in health care. ${ }^{61}$ Their messages are unsurprising: As with research of any sort, one should start with a plausible and logical construct; the intervention and its implementation should be described in sufficient detail for others to replicate the work; outcomes should be clearly defined, and the context in which the research has been conducted should be described (e.g., an initiative of value in a major teaching hospital may or may not prove worthwhile in a small private institution).

\section{Conclusions}

A broad understanding of safety and quality in health care is as fundamental to advancing patient care in anesthesia as it is in any other specialty. The papers in this themed issue of the Journal should contribute substantially to such an understanding and, at the same time, reinvigorate anesthesiologists' commitment to the continued pursuit of patient safety.

The original mission of the APSF- to "ensure that no patient is harmed by anesthesia"-remains elusive, and it should continue to be our aspiration everywhere. It is important to recognize that harm may arise not only from accidents that occur during anesthesia but also from a lack of access to effective surgery provided under safe anesthesia with adequate perioperative care. We need a patientcentred approach that is population-oriented at the same time. Our goal must be improved outcomes for our patients, and these will not be achieved in the face of inefficiency or through the provision of untimely, ineffective, or unwanted services.

We need to work collaboratively with our colleagues in surgery, nursing, and health care administration, as well as with our patients, first, to ensure the right things are done and, second, to ensure they are done right the first time.

\section{Panorama de la qualité et de la sécurité des soins de santé}

La sécurité des patients est primordiale pour les anesthésiologistes. Toutefois, d'autres facettes qui touchent à la qualité des soins de santé méritent également notre attention. L'anesthésie n'est pas un traitement en soi, mais elle est essentielle pour obtenir de bons pronostics chez les 
patients subissant une chirurgie; pour cette raison, elle est tout aussi importante que tout autre aspect des soins aux patients. En outre, en anesthésie, les défis à relever, les ressources requises et les risques encourus par les patients sont souvent égaux, voire supérieurs, à ceux liés à la chirurgie. Ces enjeux se reflètent dans les normes élevées de formation, de pratique et de recherche qui sont caractéristiques de l'anesthésie moderne dans de nombreuses parties (mais pas toutes) du monde. Ces normes ont été durement acquises; des efforts et des investissements considérables continueront d'être indispensables si l'on souhaite les maintenir et les faire avancer, en dépit de restrictions financières croissantes au niveau international. Ainsi, il incombe aux anesthésiologistes de comprendre la manière dont les services qu'ils fournissent contribuent à la qualité globale des soins de santé.

\section{L'importance capitale de la sécurité en anesthésie}

De nombreux patients subissent des torts qui auraient pu être évités en recevant des soins de santé dont l'objectif était de les aider. ${ }^{1}$ Voilà plus d'une décennie, l'Institute of Medicine américain avait lancé un appel pour des initiatives réduisant ces torts. ${ }^{2}$ Ainsi, il est gratifiant de savoir que les anesthésiologistes ont depuis longtemps la réputation de faire avancer la sécurité des patients, ${ }^{3}$ ce que de nombreux exemples confirment, notamment : la création en 1985 de l'APSF américaine (Anesthesia Patient Safety Foundation), la Fondation pour la sécurité des patients en anesthésie, sous le leadership de Jeep Pierce, ${ }^{4}$ dont la mission est de «garantir qu'aucun patient ne subit de tort causé par l'anesthésie »; en 1988, la création par Bill Runciman de l'Australian Patient Safety Foundation, la Fondation australienne pour la sécurité des patients, ${ }^{5}$ dont l'objectif était de réduire le tort fait aux patients; à la même époque, l'introduction en anesthésiologie des concepts de la « Théorie de l'accident normal » par David Gaba; ${ }^{6}$ l'adoption précoce des comptes rendus d'incidents et des leçons à en tirer, y compris des accidents évités de justesse (ou near-miss), par Jeff Cooper ${ }^{7}$ et Bill Runciman; ${ }^{8}$ et l'adoption de la simulation comme outil d'enseignement et de recherche en anesthésie. ${ }^{9-12}$

L'anesthésie étant intrinsèquement dangereuse, l'insistance énorme mise sur la sécurité des patients est justifiée. Même dans les régions du monde où les ressources ne sont pas un problème, ce n'est que relativement récemment que d'importantes réductions de la mortalité liée à l'anesthésie sont survenues. ${ }^{13}$ Dans certaines régions à faible revenu, les ressources disponibles pour l'anesthésie sont totalement inadaptées et la mortalité périopératoire atteint des proportions absolument inacceptables. ${ }^{14}$ Même dans les régions à revenu élevé, le débat fait rage concernant l'étendue des progrès réalisés et l'incidence exacte de mortalité lieee à l'anesthésie aujourd'hui. ${ }^{3,15} \mathrm{Ce}$ débat est lié en partie à l'inexistence d'un consensus international sur les définitions pertinentes. Il est tragique de constater que certains décès qui auraient pu être évités surviennent encore, pour un éventail de raisons allant des erreurs de médicaments ${ }^{16}$ à la prise en charge ratée de voies aériennes difficiles. ${ }^{17}$ Chez les patients âgés qui présentent des comorbidités, la mortalité pourrait être plus importante que ce que l'on entend parfois, ${ }^{18,19}$ et elle pourrait être influencée non seulement par le déroulement de l'anesthésie mais aussi par la prise en charge de toute la période périopératoire. ${ }^{19,20}$

\section{La mortalité et la morbidité attribuables à l'anesthésie}

Étant donné l'importance capitale de la sécurité en anesthésie, il est décevant de noter que, à l'exception contestable de l'Australie et de la Nouvelle-Zélande (récemment), ${ }^{13,21}$ nous manquons de données définissant sans équivoque possible la mortalité associée à l'anesthésie aujourd'hui et son évolution au fil du temps. Traditionnellement, les données disponibles ne traitent que des premières 24 ou 48 heures postopératoires. De nombreux décès pertinents n'entrent par conséquent pas dans le décompte si l'on ne tient compte que de périodes si brèves. ${ }^{18,19}$ Ces mesures peuvent toutefois quand même être utiles pour évaluer la norme des soins en anesthésie et mesurer leur évolution au fil du temps. L'importance d'indicateurs pour définir l'état des services de chirurgie (y compris l'anesthésie) à un niveau national se reflète dans l'initiative «Une chirurgie plus sûre pour épargner des vies » de l'Organisation mondiale de la Santé, qui inclut la mise au point de plusieurs mesures simples et faciles à mettre en place dans ce but, notamment deux définitions pratiques de la mortalité périopératoire : a) l'indice de mortalité le jour de la chirurgie, et b) l'indice de mortalité hospitalière postopératoire. ${ }^{22}$ L'évaluation du premier indice devrait être possible dans tout hôpital réalisant des chirurgies sous anesthésie, et le second dans la plupart des hôpitaux. Là où les ressources sont plus importantes, une période plus longue (par ex. 30 jours) permettra d'obtenir une idée plus précise de la mortalité liée à l'anesthésie. Il vaut également la peine d'inclure les patients n'ayant pas subi de chirurgie alors qu'elle aurait pu leur sauver la vie ainsi que les patients ayant subi des interventions sous anesthésie qui ne sont traditionnellement pas considérées comme des interventions chirurgicales (par ex. une angioplastie ou une endoscopie). ${ }^{21}$ L'analyse des cas afin de déterminer la cause du décès prend beaucoup de temps, mais elle peut apporter des informations utiles à l'amélioration des soins pour les patients futurs. Les données probantes indiquant que le travail en équipe et la communication sont des composantes déterminantes du pronostic s'accumulent. ${ }^{23-27}$ Par conséquent, il est important de comprendre non seulement le rôle des facteurs liés à la 
chirurgie, à l'anesthésie et au patient, mais aussi de l'interaction entre ces facteurs. C'est pourquoi, si l'analyse est réalisée par des membres de toute l'équipe périopératoire plutôt que par un seul groupe de métier, elle aura plus de chances d'être productive.

L'anesthésie engendre plus souvent de la morbidité que de la mortalité; pour cette raison, la morbidité devrait également être passée en revue et rapportée. Des leçons utiles peuvent être tirées de l'analyse de tous les cas dans lesquels du tort a été fait ou aurait pu être fait. ${ }^{13}$

\section{Les coûts croissants des soins de santé et le Triple objectif}

Dans de nombreux pays, au cours des dernières décennies, les coûts des soins de santé ont augmenté plus rapidement que le produit intérieur brut (PIB). ${ }^{28}$ Par exemple, les dépenses liées aux soins de santé aux États-Unis en 2001 se chiffraient à 13,5\% du PIB. Ces dépenses ont atteint $16 \%$ en 2007, et les projections prédisent qu'elles atteindront près de $20 \%$ d'ici 2020. Cette tendance s'est manifestée dans un contexte de défis financiers internationaux qu'on n'avait pas connus depuis la grande dépression des années 1930. Le «Triple objectif » (Triple Aim) de l'Institut américain pour l'amélioration des soins de santé (Institute for Healthcare Improvement) résume le besoin de restreindre cette augmentation des dépenses en maximisant les performances dans les soins de santé. ${ }^{29,30}$

Ainsi, il faut travailler simultanément sur trois plans:

- Améliorer l'expérience de soins du patient (y compris la qualité et la satisfaction);

- Améliorer la santé de la population; et

- Réduire le coût par personne des soins de santé.

Une amélioration adoptée au niveau national en Nouvelle-Zélande ${ }^{31}$ a reformulé le troisième objectif, qui consiste désormais à «obtenir la meilleure valeur des ressources du système de santé public ». Cette modification reflète un point de vue selon lequel il ne serait pas indispensable de réduire les dépenses en soins de santé (pour le moins dans les pays où elles sont considérablement plus basses qu'aux États-Unis), mais selon lequel on ne peut certainement pas se permettre de gaspillage.

Intuitivement, il semble que l'atteinte de ces trois objectifs sera grandement facilitée par deux objectifs primaires : a) bien faire les choses et b) bien les faire la première fois. La sécurité est primordiale, mais les autres composantes de la qualité sont également importantes. Outre la sécurité, effectuer le travail au bon moment, avec efficience, efficacité et équitabilité, avec le patient au centre des préoccupations. En anglais, on utilise l'acronyme
STEEEP (safety, timeliness, efficiency, efficacy, equitability, patient-centredness). ${ }^{32}$

\section{L'amélioration de la qualité dans les soins de santé}

Un élément central du rôle des anesthésiologistes est de faciliter la fourniture en temps opportun d'interventions cruciales. Toutefois, il faut encore s'occuper de problèmes récurrents en matière de fourniture en temps opportun de certains aspects importants de la pratique de l'anesthésie. Un élément clé de la Liste de contrôle de la sécurité chirurgicale $^{23}$ de l'Organisation mondiale de la Santé (OMS) touche à la nécessité de garantir l'administration en temps opportun d'antibiotiques en prophylaxie, lorsque cela est indiqué. Pour la prise en charge de difficultés imprévues au niveau des voies aériennes des patients, il est crucial de progresser au moment opportun à travers les étapes d'un algorithme adapté, mais il arrive encore fréquemment que ce ne soit pas le cas. ${ }^{17}$

Les moteurs de l'efficience sont solides en anesthésie. L'inefficience crée des coûts de renonciation qui pourraient avoir un impact négatif sur les devenirs, particulièrement au niveau de la population. L'argent dépensé pour une chose ne peut l'être pour une autre; les ressources sont limitées, et un mauvais accès à un traitement efficace est une source majeure de tort dans les soins de santé. Cela étant dit, l'efficience devrait être évaluée en fonction des résultats obtenus avec les ressources disponibles. Des services d'anesthésie plus rapides et à coût plus bas ne vont pas nécessairement de pair avec des économies globales, et il suffit d'un petit peu de tort pour contrebalancer toute économie réalisée en 'coupant les coins ronds'. Le Triple objectif $^{30}$ est utile car il met en mots la nécessité de trouver un juste équilibre entre l'efficience et les autres éléments de la qualité dans les soins de santé, particulièrement dans sa version néozélandaise, ${ }^{31}$ laquelle insiste sur l'obtention de la meilleure valeur possible à partir des ressources disponibles plutôt que sur la réduction indispensable des coûts.

Un service efficient et en temps opportun n'a que peu de valeur si les traitements offerts ne sont pas efficaces. Il faut faire une distinction entre efficacité et effectivité, et toutes deux sont importantes. L'effectivité est liée à l'impact sur les résultats d'un traitement, d'un médicament ou d'une intervention en particulier (par ex. pour améliorer la sécurité) dans la pratique réelle. Les anesthésiologistes ont l'habitude d'utiliser des médicaments très efficaces de façon 'effective' - nombre de nos agents fonctionnent chaque fois (le nombre de sujets à traiter est un), mais il faut apporter beaucoup de soin et porter une attention particulière aux détails pour les utiliser efficacement sans 
tuer nos patients. L'item « antibiotique » de la Liste de contrôle de la sécurité chirurgicale de l'OMS a pour but d'améliorer l'effectivité des antibiotiques dont l'efficacité est prouvée. $^{23}$ Des études randomisées contrôlées (ERC) d'envergure qui traitent de questions simples mais importantes dans la pratique clinique, avec comme critères d'évaluation des devenirs significatifs pour les patients, sont la pierre angulaire pour faire avancer l'efficacité en anesthésie; plusieurs excellents exemples ont été publiés au cours des dernières années. ${ }^{33-36}$ La mise sur pied de réseaux formels tel que le Outcomes Research Consortium, ${ }^{37}$ le groupe d'études du Collège australien et néozélandais des anesthésistes (Australian and New Zealand College of Anaesthetists (ANZCA) Trials Group), ${ }^{38}$ et le groupe d'essais cliniques de la Société de soins intensifs australienne et néozélandaise (Australian and New Zealand Intensive Care Society (ANZICS) Clinical Trials Group) ${ }^{39}$ a grandement facilité la réalisation d'ERC d'envergure et d'excellente qualité. Ces études fournissent des données probantes fiables et pertinentes d'un point de vue clinique afin de guider la prise en charge de patients subissant une chirurgie ou nécessitant des soins intensifs.

En tant qu'anesthésiologiste, il pourrait être tentant de ne pas penser à l'équitabilité et d'adopter le point de vue que notre seule responsabilité, quel que soit le moment dans le temps, est le bien-être du patient présent. Étant donné les contraintes en matière de ressources présentées plus haut, cette position est tout simplement intenable. ${ }^{28}$ Des bases solides nous permettent de croire que l'amélioration de l'équitabilité des soins de santé améliore les devenirs de tous, pas seulement des segments de population précédemment désavantagés. ${ }^{40}$ L'une des raisons de cette conviction repose sur le phénomène de la variation injustifiée dans les soins de santé. Nous sur-traitons certains patients alors que nous en sous-traitons d'autres; une redistribution plus équitable des soins de santé règlerait ces deux problèmes sans nécessiter d'augmentation des ressources. L'idée selon laquelle 'plus, c'est mieux' dans les soins de santé fait partie inhérente de la culture de nombreuses sociétés modernes, et la motivation à promouvoir ce point de vue est considérable pour les professionnels des soins de santé. Dès lors, il est intéressant de constater que les taux de mortalité tendent à stagner, voire à baisser, lorsque les médecins se mettent en grève. ${ }^{41}$ Ces résultats en apparence paradoxaux peuvent s'expliquer de plusieurs façons, mais ils s'alignent avec d'autres données probantes ${ }^{1,2}$ qui (pour citer les auteurs) soulignent « les risques des chirurgies non urgentes, qui pourraient en fait augmenter la mortalité. Elles soulignent aussi la possibilité qu'une surabondance de médecins pourrait ne pas augmenter la survie du patient et pourrait introduire des inefficiences dans les soins de santé ». ${ }^{41}$
Avant de traiter de la variation dans les soins de santé de façon plus détaillée, il convient de réfléchir à l'importance des soins centrés sur le patient. ${ }^{42}$ Il est de plus en plus clair que des patients bien informés n'exigent pas forcément tous les traitements à leur disposition. ${ }^{1,43}$ Les patients qui s'impliquent dans leurs soins et ont une compréhension raisonnable de leurs options (y compris l'option de ne rien faire) feront probablement de meilleurs choix et contribueront de façon plus constructive à leur propre sécurité que des patients qui ne s'impliquent pas. ${ }^{44} \mathrm{Il}$ est également important que tous ceux qui sont impliqués dans les soins des patients au sein du système complexe des soins de santé moderne communiquent de façon constructive entre eux et qu'ils présentent un front commun dans leurs messages aux patients et dans leurs efforts pour les traiter. ${ }^{45}$ L'impact d'un meilleur travail d'équipe et d'une meilleure communication sur le pronostic de la chirurgie a été mentionné plus haut. ${ }^{23-27}$ En adoptant une approche collaborative à la fois interprofessionnelle et centrée sur le patient, nous mettons toutes les chances de notre côté pour réussir à offrir aux patients des résultats compatibles avec leurs propres valeurs plutôt qu'avec les valeurs que les professionnels de la santé perçoivent comme importantes.

\section{Les variations dans les soins de santé}

Même dans les pays riches, il existe souvent d'importantes disparités dans les soins reçus par les patients et les résultats de ces soins. ${ }^{46,47}$ Par exemple, Birkmeyer et coll. ont montré que l'incidence de consultations pour une endartériectomie carotidienne pour les patients inscrits à Medicare aux États-Unis variait d'un facteur d'à peu près 10 entre la région ayant la plus grande incidence et celle dont l'incidence était la plus faible. ${ }^{46}$ La disparité fondée sur les différences entre patients est adaptée, mais cette variation ne s'explique pas par la clientèle ou par des différences en matière de ressources. Plutôt, ce type de variation semble refléter des différences typiquement régionales au niveau de l'approche des professionnels, ${ }^{46,48}$ bien que les préjugés d'une part et les préférences des patients d'autre part puissent également être des facteurs. ${ }^{49-51}$ Les domaines qui reçoivent les plus importants investissements dans les soins de santé ou le plus d'interventions ne produisent pas forcément les meilleurs résultats. ${ }^{51}$

Le fait de souligner les variations seules ne nous permet pas de déterminer quel taux de variation est acceptable; toutefois, lorsque les patients évalués sont équivalents, les taux les plus élevés et les plus bas ne peuvent ni l'un ni l'autre être justes. Dans les soins de santé, les variations comprennent en règle générale le sous-traitement et le sur-traitement, tous deux porteurs de risque pour le patient. 
Un traitement adapté comporte également des risques; dans un tel cas toutefois, le risque est justifié par des attentes raisonnables quant aux bienfaits. Par contre, si une erreur causant du tort est faite au cours d'une intervention qui n'était pas véritablement justifiée par des données probantes d'efficacité ou lors d'une intervention qui n'aurait pas été véritablement souhaitée par le patient s'il avait été adéquatement informé, alors la cause fondamentale d'un tel tort n'est pas l'erreur (qui est davantage une cause proximale) mais plutôt la décision de réaliser l'intervention en soi. Même si elles sont réalisées sans faute, de telles interventions entraînent un coût de renonciation.

La variation dans la fourniture des soins de santé est particulièrement évidente à l'échelle internationale. En effet, environ $35 \%$ de la population mondiale a accès à seulement $3,5 \%$ des 230 millions d'interventions chirurgicales réalisées dans le monde chaque année, ${ }^{52}$ et la qualité des soins en anesthésie offerts à ces personnes est en général inadéquate. ${ }^{14}$ Les régions du monde à faible revenu (dont certaines se trouvent dans des pays ayant en moyenne des revenus élevés ou moyens) sont celles qui présentent le plus fort potentiel d'amélioration au niveau des résultats globaux des soins de santé (y compris l'anesthésie). Ce potentiel ne réside pas dans le fait de continuer d'accepter des soins inadaptés comme étant inévitables; plutôt, il réside dans des initiatives destinées à élever les normes jusqu'à un niveau acceptable au moindre coût. $^{53,54}$

\section{La mesure et l'évaluation}

Bien que certaines initiatives devraient être entreprises simplement par ce qu'elles sont logiques, ${ }^{55}$ il faut mesurer pour améliorer la qualité, et il ne faut pas oublier la possibilité d'effets 'vengeurs' inattendus découlant d'initiatives bien intentionnées. ${ }^{56}$ Le cadre de structure, processus et résultats de Donabedian est couramment utilisé. ${ }^{57}$ Les mesures de résultats sont les plus importantes, tout en étant les plus difficiles à mesurer. Les mesures de processus peuvent être particulièrement efficaces pour promouvoir des améliorations au niveau de la qualité parce que de telles mesures (par ex. le taux de lavage des mains) ne sont en général pas influencées par le type de cas traités. Dès lors, les comparaisons entre diverses institutions ou au fil du temps sont souvent plus fiables que les comparaisons de résultats (par ex. l'incidence d'infections associées aux soins de santé).

La survie est un résultat important qui capte l'imagination du public, c'est pourquoi il n'est pas surprenant que les torts iatrogéniques soient parfois quantifiés en termes de vies perdues $^{2}$ ou que certaines initiatives de sécurité aient promu explicitement l'objectif de sauver des vies. ${ }^{58}$ En fait, les vies perdues ou sauvées se sont avérées difficiles à mesurer. ${ }^{59,60}$ L'attribution de la cause de décès est souvent difficile dans le contexte d'interventions de haut niveau qui ont pour but d'améliorer le fonctionnement global d'un système de soins de santé complexe. En outre, les vies sauvées ne paraissent pas toujours égales - comment comparer les trois derniers mois de vie d'un patient âgé en mauvaise santé à la vie future entière d'un enfant en bonne santé? La mesure des années de vie ajustées en fonction de la qualité (AVAQ) semble être plus significative, bien que moins séduisante pour le public, mais le fait de passer des jugements sur la qualité de la vie d'autres personnes ne fait pas bon ménage avec le concept de soins centrés sur le patient. La mortalité, comme nous l'avons mentionné plus haut, est une autre affaire. Aux niveaux national et institutionnel, si une correction adéquate est faite pour tenir compte de la clientèle et des facteurs de risque (les catégories ASA de l'American Society of Anesthesiologists et l'âge sont tous deux significatifs dans le contexte de l'anesthésie), on peut obtenir des données objectives précieuses; un engagement plus généralisé pour mesurer la mortalité liée à l'anesthésie n'a que trop tardé.

Pronovost et coll. ont présenté un résumé très bien conçu des questions dont il faut tenir compte dans les recherches qui évaluent les initiatives de qualité et de sécurité dans les soins de santé.$^{61}$ Leurs messages sont sans surprise : comme dans toute recherche, il faut commencer par un concept plausible et logique; l'intervention et sa mise en œuvre doivent être décrites de manière suffisamment détaillée afin que d'autres puissent reproduire le travail; les résultats doivent être clairement définis, et le contexte dans lequel les recherches ont été réalisées doit être décrit (par ex. une initiative efficace dans un hôpital universitaire pourrait être utile ou non dans une petite institution privée).

\section{Conclusion}

Une compréhension globale de la sécurité et de la qualité dans les soins de santé est aussi essentielle pour faire progresser les soins donnés aux patients en anesthésie que dans toute autre spécialité. Les articles dans ce numéro spécial du Journal devraient contribuer de façon significative à une telle compréhension, tout en fournissant un regain à l'engagement des anesthésiologistes envers la poursuite continue de la sécurité des patients.

La mission originelle de l'APSF - de «garantir qu'aucun patient ne subit de tort causé par l'anesthésie » - demeure hors d'atteinte, et nous devrions nous efforcer d'y aspirer partout. Il est important de reconnaître que du tort peut être causé non seulement en cas d'accidents survenant pendant l'anesthésie mais également si un patient n'a pas accès à une chirurgie efficace réalisée sous 
une anesthésie sécuritaire et bénéficiant de soins périopératoires adéquats. Il nous faut une approche centrée sur le patient qui soit simultanément orientée vers la population. Notre objectif doit être d'améliorer les indicateurs de santé de nos patients, et nous n'y parviendrons pas si nous sommes confrontés à l'inefficacité ou si nos services sont fournis au mauvais moment, sont inefficaces ou ne sont pas désirés.

Il nous faut travailler en collaboration avec nos collègues de chirurgie, des soins infirmiers et de l'administration des soins de santé, ainsi qu'avec nos patients, pour d'une part garantir que les bons gestes sont posés, et d'autre part qu'ils sont bien posés dès la première fois.

Acknowledgements Thank you to Professors Jeff Cooper and Bill Runciman for their advice and information and to Mr. David Merry, Associate Professor Sally Merry, and Dr. Daniel Devcich for reading and commenting on the manuscript.

Conflicts of interest A. F. Merry has financial interests in Safer Sleep LLC. He is a member of the Executive Committee of the World Federation of Societies of Anesthesiologists and is a member of the Lifebox Foundation Board.

Competing interests None declared.

\section{References}

1. Runciman B, Merry A, Walton M. Safety and Ethics in Healthcare: A Guide to Getting it Right. Aldershot: Ashgate Publishing Ltd.; 2007.

2. Kohn LT, Corrigan JM, Donaldson MS. To Err is Human: Building a Safer Health System. Washington DC: National Academy Press; 1999.

3. Cooper JB, Gaba D. No myth: anesthesia is a model for addressing patient safety. Anesthesiology 2002; 97: 1335-7.

4. Cooper J. Patient Safety and Biomedical Engineering. In: Kitz R (Ed.). This is No Humbug: Reminiscences of the Department of Anesthesia at the Massachusetts General Hospital. Boston: Department of Anesthesia and Critical Care, Massachusetts General Hospital, USA; 2002: 377-420.

5. Runciman WB. The Australian Patient Safety Foundation. Anaesth Intensive Care 1988; 16: 114-6.

6. Gaba DM, Maxwell M, DeAnda A. Anesthetic mishaps: breaking the chain of accident evolution. Anesthesiology 1987; 66: 670-6.

7. Cooper JB, Long CD, Newbower RS, Philip JH. Critical incidents associated with intraoperative exchanges of anesthesia personnel. Anesthesiology 1982; 56: 456-61.

8. Runciman WB, Sellen A, Webb RK, et al. The Australian Incident Monitoring Study. Errors, incidents and accidents in anaesthetic practice. Anaesth Intensive Care 1993; 21: 506-19.

9. Denson JS, Abrahamson S. A computer-controlled patient simulator. JAMA 1969; 208: 504-8.

10. Gaba DM, DeAnda A. A comprehensive anesthesia simulation environment: re-creating the operating room for research and training. Anesthesiology 1988; 69: 387-94.

11. Schwid HA. A flight simulator for general anesthesia training. Comput Biomed Res 1987; 20: 64-75.

12. Good ML, Gravenstein JS. Anesthesia simulators and training devices. Int Anesthesiol Clin 1989; 27: 161-8.
13. Gibbs NM. Milestones in anaesthesia-related mortality and morbidity reporting in Australia. Anaesth Intensive Care 2010; 38: 807-8.

14. Walker IA, Wilson IH. Anaesthesia in developing countries - a risk for patients. Lancet 2008; 371: 968-9.

15. Lagasse RS. Anesthesia safety: model or myth? A review of the published literature and analysis of current original data. Anesthesiology 2002; 97: 1609-17.

16. Eichhorn $J H$. APSF hosts medication safety conference: consensus group defines challenges and opportunities for improved practice. APSF Newsletter (Spring) 2010; 25: 1-7.

17. Greenland $K B$, Acott $C$, Segal R, Goulding G, Riley RH, Merry $A F$. Emergency surgical airway in life-threatening acute airway emergencies - why are we so reluctant to do it? Anaesth Intensive Care 2011; 39: 578-84.

18. Story DA, Leslie K, Myles PS, et al. Complications and mortality in older surgical patients in Australia and New Zealand (the REASON study): a multicentre, prospective, observational study. Anaesthesia 2010; 65: 1022-30.

19. Vascular Events in Noncardiac Surgery Patients Cohort Evaluation Study Investigators; Devereaux PJ, Chan MT, Alonso-Coello P, et al. Association between postoperative troponin levels and 30day mortality among patients undergoing noncardiac surgery. JAMA 2012; 307: 2295-304.

20. Mangano DT, Browner WS, Hollenberg M, London MJ, Tubau $J F$, Tateo IM. Association of perioperative myocardial ischemia with cardiac morbidity and mortality in men undergoing noncardiac surgery. The Study of Perioperative Ischemia Research Group. N Engl J Med 1990; 323: 1781-8.

21. Health Quality and Safety Commission New Zealand. Perioperative Mortality Review Committee (POMRC). Perioperative Mortality in New Zealand: Inaugural report of the Perioperative Mortality Review Committee. Wellington, New Zealand. Health Quality \& Safety Commission. 2011. Available from URL: http://www.pomrc.health.govt.nz (accessed August 2012).

22. Weiser TG, Makary MA, Haynes AB, et al. Standardised metrics for global surgical surveillance. Lancet 2009; 374: 1113-7.

23. Haynes $A B$, Weiser $T G$, Berry WR, et al. A surgical safety checklist to reduce morbidity and mortality in a global population. N Engl J Med 2009; 360: 491-9.

24. Haynes $A B$, Weiser TG, Berry WR, et al. Changes in safety attitude and relationship to decreased postoperative morbidity and mortality following implementation of a checklist-based surgical safety intervention. BMJ Qual Saf 2011; 20: 102-7.

25. Neily J, Mills PD, Young-Xu Y, et al. Association between implementation of a medical team training program and surgical mortality. JAMA 2010; 304: 1693-700.

26. de Vries EN, Prins HA, Crolla RM, et al. Effect of a comprehensive surgical safety system on patient outcomes. N Engl J Med 2010; 363: 1928-37.

27. Birkmeyer JD. Strategies for improving surgical quality-checklists and beyond. N Engl J Med 2010; 363: 1963-5.

28. Davis K, Schoen C, Stremikis K. Mirror, Mirror on the Wall: How the Performance of the U.S. Health Care System Compares Internationally 2010 Update: The Commonwealth Fund, June 2010. Available from URL: http://www.commonwealthfund.org/Publications/Fund-Reports/2010/Jun/Mirror-Mirror-Update.aspx?page $=$ all (accessed August 2012).

29. Berwick DM, Nolan TW, Whittington J. The triple aim: care, health, and cost. Health Aff (Millwood) 2008; 27: 759-69.

30. Institute for Healthcare Improvement. IHI Triple Aim. Boston, 2012. Available from URL: http://www.ihi.org/offerings/Initiatives/TripleAim/Pages/default.aspx (accessed July 2012).

31. Health Quality \& Safety Commission. The Triple Aim, 2011. Available from URL: http://www.hqsc.govt.nz/news-and-events/ news/126/ (accessed July 2012). 
32. Institute of Medicine. Crossing the Quality Chasm: A New Health System for the 21st Century. Washington, DC: National Academy Press; 2001.

33. Myles PS, Leslie K, McNeil J, Forbes A, Chan MT. Bispectral index monitoring to prevent awareness during anaesthesia: the B-Aware randomised controlled trial. Lancet 2004; 363: 1757-63.

34. Group PoiseStudy, Devereaux PJ, Yang H, et al. Effects of extended-release metoprolol succinate in patients undergoing non-cardiac surgery (POISE trial): a randomised controlled trial. Lancet 2008; 371: 1839-47.

35. Myles PS, Leslie K, Chan MT, et al. Avoidance of Nitrous Oxide for Patients Undergoing Major Surgery: A Randomized Controlled Trial. Anesthesiology 2007; 107: 221-31.

36. Finfer $S$, Bellomo R, Boyce $N$, et al. A comparison of albumin and saline for fluid resuscitation in the intensive care unit. $\mathrm{N}$ Engl $\mathrm{J}$ Med 2004; 350: 2247-56.

37. Outcomes Research Consortium - 2012. Available from URL: http://www.or.org/ (accessed July 2012).

38. Story DA, Myles PS. Large multicentre trials in anaesthesia: the ANZCA clinical trials group. Anaesth Intensive Care 2005; 33: 301-2.

39. Bellomo R. The ANZICS clinical trials group. Crit Care Resusc 2000; 2: 9-10.

40. Pickett $K$, Wilkinson $R$. The Spirit Level: Why Greater Equality Makes Societies Stronger. New York: Bloomsbury Press; 2009.

41. Cunningham SA, Mitchell K, Narayan KM, Yusuf S. Doctors' strikes and mortality: a review. Soc Sci Med 2008; 67: 1784-8.

42. Barry MJ, Edgman-Levitan S. Shared decision making-pinnacle of patient-centered care. N Engl J Med 2012; 366: 780-1.

43. Wright JG, Santaguida PL, Young N, Hawker GA, Schemitsch E, Owen JL. Patient preferences before and after total knee arthroplasty. J Clin Epidemiol 2010; 63: 774-82.

44. Cassell EJ. Consent or obedience? Power and authority in medicine. N Engl J Med 2005; 352: 328-30.

45. Bodenheimer T. Coordinating care - a perilous journey through the health care system. N Engl J Med 2008; 358: 1064-71.

46. Birkmeyer JD, Sharp SM, Finlayson SR, Fisher ES, Wennberg $J E$. Variation profiles of common surgical procedures. Surgery 1998; 124: 917-23.

47. McGlynn EA, Asch SM, Adams J, et al. The quality of health care delivered to adults in the United States. N Engl J Med 2003; 348 : 2635-45.
48. Toronto Arthroplasty Research Group Writing Committee; Wright JG, Hawker GA, Hudak PL, et al. Variability in physician opinions about the indications for knee arthroplasty. J Arthroplasty $2011 ; 26$ : 569-75.e1.

49. Hawker GA, Wright JG, Coyte PC, et al. Determining the need for hip and knee arthroplasty: the role of clinical severity and patients' preferences. Med Care 2001; 39: 206-16.

50. Borkhoff CM, Hawker GA, Kreder HJ, Glazier RH, Mahomed $N N$, Wright JG. Patients' gender affected physicians' clinical decisions when presented with standardized patients but not for matching paper patients. J Clin Epidemiol 2009; 62: 527-41.

51. Kwok AC, Semel ME, Lipsitz SR, et al. The intensity and variation of surgical care at the end of life: a retrospective cohort study. Lancet 2011; 378: 1408-13.

52. Weiser TG, Regenbogen SE, Thompson KD, et al. An estimation of the global volume of surgery: a modelling strategy based on available data. Lancet 2008; 372: 139-44.

53. Merry AF, Cooper JB, Soyannwo O, Wilson IH, Eichhorn JH. International Standards for a Safe Practice of Anesthesia 2010. Can J Anesth 2010; 57: 1027-34.

54. Walker IA, Merry AF, Wilson IH, et al. Global oximetry: an international anaesthesia quality improvement project. Anaesthesia 2009; 64: 1051-60.

55. Leape $L L$, Berwick DM, Bates DW. What practices will most improve safety? Evidence-based medicine meets patient safety. JAMA 2002; 288: 501-7.

56. Tenner E. Why Things Bite Back - Technology and the Revenge of Unintended Consequences. New York: Vintage Books; 1997.

57. Donabedian A. An Introduction to Quality Assurance in Health Care. New York: Oxford University Press; 2003.

58. Berwick DM, Calkins DR, McCannon CJ, Hackbarth AD. The 100,000 lives campaign: setting a goal and a deadline for improving health care quality. JAMA 2006; 295: 324-7.

59. Hayward RA, Hofer TP. Estimating hospital deaths due to medical errors: preventability is in the eye of the reviewer. JAMA 2001; 286: 415-20.

60. Wachter RM, Pronovost PJ. The 100,000 Lives Campaign: a scientific and policy review. Jt Comm J Qual Patient Saf 2006; 32: 621-7.

61. Shekelle PG, Pronovost PJ, Wachter RM, et al. Advancing the science of patient safety. Ann Intern Med 2011; 154: 693-6. 